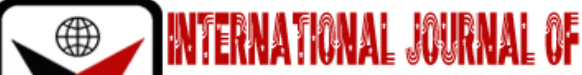



ISSN 2278-0211 (Online)

\section{Difficulties in English Speaking Skills of Non-English Majored Freshmen at a University}

\author{
Nhung Hong Thi Pham \\ Lecturer, Faculty of Foreign Languages, University of Cuu Long, Vietnam \\ HuanBuu Nguyen \\ Associate Professor in Education, \\ School of Foreign Languages, Can Tho University, Vietnam
}

\begin{abstract}
:
Speaking has been widely thought as the most effective way for students to learn and communicate English as a foreign language. However, this oral skill is a challenging task to university students. This study therefore focuses on the difficulties encountered by non-English majored freshmen while learning speaking English as a foreign language at a university in the Mekong Delta region. The study also explores whether there are any statistically significant differences from the variable of gender of the students. It was a descriptive study using questionnaire. The quantitative data from the questionnaire were undertaken with 103 freshmen at a university. The findings indicated students' difficulties while learning speaking English were associated with linguistic and instructor domains. Implications for further practices are discussed.
\end{abstract}

Keywords: Difficulties, speaking English, domain

\section{Introduction}

English has become an international language that more and more people use it to communicate and exchange ideas and share knowledge with others. Recent reforms in educational system in Vietnam have indicated the role of English as one of compulsory subjects taught from the elementary to the university levels. Thus, good command of English language is needed for students to succeed in their academic learning contexts. However, of the four English skills, speaking is viewed as one of the most challenging skills for students in their learning process to communicate and interact with others, as noted by Khamkhien (2010). Moreover, most freshmen in this study were likely to have difficulties in speaking English, namely pronunciation issues, vocabularies, grammar, fluency and comprehension while learning speaking English. Therefore, this study was conducted to find out the difficulties non-English majored students encountered and to explore gender differences.

The following section reviews the literature on four concepts: speaking, aspects of English speaking skill, factors hindering student speaking, and gender differences in learning speaking skill.

\section{Literature Review}

\subsection{SpeakingSkill}

There are several definitions of speaking skill in English as a foreign language (EFL). Speaking is a kind of bridge for learners between classroom and the world outside (Hadfield, 1999). Speaking is the verbal use of language and a medium through which human beings communicate with each other (Fulcher, 2003). According to Nunan (2003), speaking is "the productive oral skill. It consists of producing systematic verbal utterance to convey meaning." (p.48). Furthermore, Scoot (2005) claims that speaking is "the productive and oral skill. Speaking is a cognitive skill, is the idea that knowledge increases automatically through successive practice." (p.79). Kayi (2006) adds that speaking is the process of building and sharing meaning through the use of verbal and non-verbal symbols, in a variety of contexts. Taken all together, speaking is an interaction between speakers with listeners. In this study, speaking is defined as the ability to produce meaningful utterances/ discourse orally to address other people and to be accurate in using grammar and vocabulary.

\subsection{Aspects of Speaking English skill}

This section presents the aspects of speaking English, namely pronunciation, grammar, vocabulary, fluency and comprehension. 


\subsubsection{Pronunciation}

Pronunciation is the act or manner of the speakers that produce cleaner language when they speak. It includes the segmental features, vowels, consonants, word stress, tone pitch and intonation patterns. For that reason, if the speakers want to be able to speak English fluently, they need to be able to pronounce phonemes correctly, use the appropriate stress and intonation patterns and speak in connected speech. Harmer (2001) provides more issues related to pronunciation. He suggests pitch, intonation, individual sounds, sounds and spelling, and stress. According to Thornbury (2005), pronunciation refers to the student's ability to produce comprehensible utterances to fulfill the task requirements.

\subsubsection{Grammar}

Grammar is the basic units of meaning, such as words and a set of rules to combine them into a new sentence (Fromkin\& Rodman, 1998). It is essential for the speakers in a good conversation. According to Brown (2001) "Grammar is the system of rules governing the conventional arrangement and relationship of words in a sentence". Moreover, according to Thornbury (2005), learners' correct use of grammatical structures requires the length and complexity of the utterances and the well-structured clauses.

\subsubsection{Vocabulary}

Vocabulary is a very basic element in English language learning of speaking. It includes a single word, set phrases, variable phrases, phrasal verbs and idioms. One cannot effectively communicate or express their ideas both in oral and written form if they do not have sufficient vocabulary. Thornbury (2005) suggests three usual things used by speakers in what they are being said:

- When people speak, they are involving a high proportion of words and expressions that express their attitude (stance) to what is being said.

- $\quad$ Speakers usually employ words and expressions that express positive and negative appraisal because a lot of speech has an interpersonal function, and by identifying what people like and dislike, they are able to express solidarity.

- A speech also usually employs deictic language, i.e. words and expressions that point to the place, time, and participants in the intermediate or a more distant context.

\subsubsection{Fluency}

Fluency is the ability to talk freely without too much stopping or hesitating. When speaking fluently, the speakers are able to get the message across with whatever resources and abilities they have got, regardless of grammatical and other mistakes. Hedge (2000) expressed that fluency is the ability to answer coherently by connecting the words and phrases, pronouncing the sounds clearly, and using stress and intonation. According to Hughes (2002), fluency is the learners' ability to speak in an understandable way in order not to break down communication because listeners may lose their interest. Fluency is the extent to which the learner can speak at an acceptable speed with few false starts and hesitations (Nunan, 2015).

\subsubsection{Comprehension}

Comprehension is defined as an individual's ability to understand a particular text of a subject. Even though speaking seems to be the most important skills of all the four skills, people know a language are usually referred to as speakers of that language (Ur, 1996). The major goal of English language teaching is to give learners the ability to use English effectively and accurately while communicating and interacting with others.

\subsection{Factors That May Cause Speaking Difficulties to Students}

\subsubsection{Psychological Domain}

Burns and Joyce (1997) argue that psychological factors such as anxiety or shyness, lack of confidence, lack of motivation, and fear of mistakes are the factors commonly that hinder students from speaking. Motivation is also an important factor in language learning success. Brown (1980) defines motivation as an inner drive, impulse, emotion or desire that moves one to a particular action. It's known to all that proper motivation will draw learners' attention and arouse their interests to learn, thus they are more likely to succeed in language learning. Furthermore, Brown claimed that there is not successful cognitive or affective activity that can be carried out without some degree of self- esteem, selfconfidence, knowledge of yourself, and belief in your own capabilities for that activity (Brown, 2002).

On the other hand, Juhana (2012) said that psychological or affective factors often influence the students' difficulties in learning to speak, such as fear of mistakes, shyness, anxiety, lack of confidence and motivation. Goh and Burns (2012) noted that anxiety has a negative effect on the learning process and learners who suffer from language anxiety feel that speaking another language is a stressful experience. This experience hinders learners and makes them avoid or withdraw from active oral interactions. Speakers also worry about how listeners evaluate and view them. Alhmadi (2014) indicated that anxiety is considered an influential intrinsic factor in the acquisition of speaking and oral communication skills.

Furthermore, in speaking, confidence plays an important role in improving students' proficiency. Generally, students who are self-confident can learn better because they are brave and believe in their abilities. Krashen (1982) argues that learners with high motivation, self-confidence, a good self-image, and a low level of anxiety are better equipped for success in second language acquisition. Krashen (1982) suggests that language teachers can help students 
gain self-confidence by providing them proper language for social situations, good chances to practise the language and an attractive classroom environment.

\subsubsection{Instructor Domain}

Teachers should use some helpful techniques to heighten their students' awareness of these language components. Harmer (1991) states that teachers' mistake correction while their learners are speaking can be considered to limit the learners' confidence in speaking performance. Besides, using interesting materials the students will be wellmotivated to take part in the process of teaching and learning. Brown (2000) states that the material used in teaching English should be suitable with students' needs. Good teaching materials should be realistic, relevant, interesting, and motivating. During the process of teaching speaking, the teacher is expected to make more variation concerning the activities applied in speaking. Nawshin (2009) also adds a number of other causes that make speaking difficult based on her research, such as lack of interesting topics which make the students not feel interested in the topic for the speaking activity. Gubaily (2012) and Alhaisoni and Rahman (2013) found that the teaching method of speaking was not satisfactory, and it required more improvement in terms of teaching methodology. Thus, teachers should change their instruction from lecture mode into a student-centered approach and use some helpful techniques to heighten their students' awareness of these language components.

\subsubsection{Social Domain}

The social context is essential because it forms a number of learning factors such as second language learners' motivation, goals and proficiency (Beebe, 1985 \&Kumaravadivelu, 2006). Wong-Fillmore (1989) concluded that social setting creates and shapes good chances for a second language learner because it develops his learning potential. In this way, learners who have plenty of opportunity to speak can achieve great fluency in speaking because they practice on a daily basis. However, in countries where English is spoken as a foreign language, students find it difficult to develop their ability to speak because they do not communicate in English in and outside school. In fact, lack of exposure to English in daily life interactions is considered one of the language barriers which limit students' ability to achieve a high level of English fluency and competence.

\subsubsection{Linguistic Domains}

\subsubsection{Pronunciation}

Pronunciation is one of the most important things that students have to master in order to communicate appropriately and fluently. The students' knowledge of how sounds are produced as well as how words are put in meaningful sentences is very essential (Canale\& Swain, 1980). As far as phonology is concerned, learners should know to pronounce sounds correctly to avoid common problems that are usually transferred from their first language. Also, they have to be aware of features of speech such as stress, intonation and rhythm. Second language learners therefore need knowledge of the language they wish to speak, an understanding of the phonetic structure of the language at the level of individual word, and understanding of intonation (Fulcher, 2003).

\subsubsection{Vocabulary}

Vocabulary is an important aspect in teaching and learning a language (Edward \&Vallette, 1997) "vocabulary is one of the important factors in all language teaching; students must continually learn words as they learn structure and as they practice sound systems". Furthermore, Laufer (1997) rehearses that vocabulary learning is at the heart of language learning and language use. In fact, it is what makes the essence of a language. Without vocabularies, speakers cannot convey the meaning and communicate in the target language.

In addition, learners should develop their own vocabulary size which helps them in their oral interactions. Goh and Burns (2012) point out that learners' lack of words can prevent them from expressing themselves accurately. They also added that learners need to know the grammar of English in order to be understood.

\subsubsection{Grammar}

According to Ur (1996), grammar is defined as the way words are put together to make correct sentences. Furthermore, Jeffrey \& Stacy (2003) shows that language grammar is a set of rules that govern its structure, which determines how words are arranged in units forming meaningful language. Similarly, Michael (2005) defines grammar as the rules that explain how words are combined, arranged, or changed to show certain kinds of meaning.

However, students face their task of speaking in the class. Brown (2001) listed six possible task categories for the classroom speaking performance as follows: imitative, intensive, responsive, transactional (dialogue), interpersonal (dialogue), and extensive (monologue). Biber (2007) believed that some academic speaking skills such as giving an oral presentation or participating in classroom discussion require a much broader range of vocabulary knowledge, grammatical sophistication and discourse competence than is the case with typical daily life conversation.

To speak fluently, learners should have adequate knowledge of English through which they can enhance their proficiency. The students should put a great deal of effort to enhance their phonological, lexical and grammatical knowledge of English. 


\subsection{Differences Between Male and Female in Learning Speaking Skill}

Gender differences can be seen not only in life but also in learning English language. It also shows clearly in learning speaking English. Tymson (1998) classifies differences on males and females in communication as seen in the following table:

\begin{tabular}{|c|c|}
\hline Male Style & Female Style \\
\hline Focus on information & Focus on relationship \\
\hline Report style of speaking & Rapport style of speaking \\
\hline Goal driven & Process oriented \\
\hline Single-task approach & Multi-task approach \\
\hline Succinct language & Storytelling style of speech \\
\hline Working towards a destination & On a journey \\
\hline Need to know the answers & Want to ask the right questions \\
\hline
\end{tabular}

Table 1

With regard to female's speaking ability in English, it is assumed that females outperformed males. Female students are commonly more active and get better scores than male students (Smith \& Wilhelm, 2002). Besides, females are not only better in reading, but also in speaking and writing (Alliance, 2007).

Furthermore, Boyd and Bee (2006) believed that there are some points in gender differences. First, males are thought to be more physically aggressive (such as hurts others physically or poses a threat of such damage) and more assertive than females do. Females are likely to express their aggressiveness in a different way using what has recently been labeled relational aggression (peer relationship by cruel gossip, ostracism, or facial expression of insult.

From above literature, this study seeks the answers to the following questions:

- What difficulties have non-English majored freshmen at a university encountered while learning speaking English?

- Are there any differences between male or female students?

\section{The Study}

This study used a descriptive research. Creswell (2013) states that the descriptive method is to gather information about the existing condition. The emphasis of this method is describing and interpreting rather than on judging information. The aim of this research is to verify formulated hypotheses that refer to the present situation in order to illustrate it. This method is advantageous to the researcher due to its flexibility. It can use either quantitative or qualitative data or both, which give the researcher more options to select the instrument for data-gathering.

The quantitative approach was implemented to explore the difficulties that non-English majored freshmen at University have encountered while learning speaking English. It also explores whether there are any statistically significant differences from the variable of gender of the students.

To collect reliable data, the questionnaire was utilized to seek the answers for the current research questions. The data were used to explore EFL freshmen's progress from English speaking class when they learned basic English one. This is a compulsory subject for non-English major freshmen at university. Furthermore, the questionnaire was also applied to measure the differences between male and female students when learning speaking. The questionnaire was administered after finishing the subject in students' class.

\section{Participants}

The participants in this study were 103 non-English major freshmen at a university in the Mekong Delta. Their ages are between 18 and 20. They have studied Basic English One, a requirement for non-English major students in the first semester of the academic years 2019-2020. Almost all participants have studied English for at least seven and a half years, but they rarely had opportunities to practice English outside the classroom. They have finished this subject in three semesters as a criterion for graduating from the University.

The participants were selected at a university in the Mekong Delta because of its convenience. They were studying at the same place where the researcher conducted her study, allowing for easy access to collecting and processing data, for example, administering the questionnaire for participants.The questionnaire was administered to 103 (49 male and 54 female) non- English majored freshmen.

\section{Data Analysis}

This questionnaire was adopted from a version of Atallah (2016). The thirty-one-item-questionnaire consists of three parts. The first part includes personal information, whereas the second part of 27 items is divided into four domains (psychological, instructor, social, and linguistic domains). Every respondent expresses the degree of his/her agreement for each scaled item, according to the five-point-Likert scale. This closed-opened questionnaire was delivered to participants to obtain the answers to the items by choosing the number ranging from 1 (strongly disagree), 2 (disagree), 3 (neutral), 4 (agree), 5 (strongly agree). 


\begin{tabular}{|c|c|}
\hline Domain & Items \\
\hline Psychological & $1-8$ \\
\hline Instructor & $9-16$ \\
\hline Social & $17-21$ \\
\hline Linguistic & $22-27$ \\
\hline Table 2 Description of Item in Each Domain
\end{tabular}

Table 2: Description of Items in Each Domain

The participants were 103 first-year students at a university. The researcher contacted the teachers of the selected class to ask for their voluntary participation. The questionnaires were filled during the class time.

The data for this study is quantitative from the questionnaire to conduct the aims of the study. The quantitative data were collected through questionnaires for students which analysis was undertaken using the Statistical Package for the Social Science (SPSS) version 20 to analyze descriptive statistics and reliability.

The descriptive statistics such as means, standard deviation was run to identify difficulties that non-English majored freshmen based on each domain; and explore whether there are any statistically significant differences from the variable of gender of the students.

\section{Findings}

\subsection{The Difficulties Freshmen Encountered in Speaking English}

\begin{tabular}{|c|c|c|c|c|c|}
\hline & N & Minimum & Maximum & Mean & Std. Deviation \\
\hline Meaneach & 103 & 1.22 & 4.67 & 3.65 & .44 \\
\hline Valid N (listwise) & 103 & \multicolumn{5}{l}{} \\
\hline
\end{tabular}

A Descriptive Statistic Test was run to find out the average level (means core) of difficulties that non-English majored freshmen have encountered while learning speaking English.

Table 4.2 shows the results of the study. It can be seen that participants' difficulties that they have encountered while learning speaking English are at a high level $(M=3.65, S D=.44)$. It can be concluded that the freshmen have encountered different difficulties in learning speaking English.

\begin{tabular}{|c|c|c|c|c|c|}
\hline & & Mean & N & Std. Deviation & Std. Error Mean \\
\hline \multirow{2}{*}{ Pair 1 } & MeanDomain1 & 3.46 & 103 & .69 & .068 \\
\cline { 2 - 6 } & MeanDomain2 & 3.74 & 103 & .43 & .042 \\
\hline
\end{tabular}

Table 4: Paired-Samples T-Test of Psychological and Instructor Domain

The Paired Samples $t$-Test was run to compare the mean scores of the student's difficulties in learning speaking English with psychological and Instructor domain. The mean score of the students' difficulties in the Psychological domain $(M=3.46, S D=.69)$ was lower than the Instructor domain $(M=3.74, S D=.43)$. The results indicated that there was a significant difference between the students' difficulties in learning English speaking with Psychological domain and Instructor domain $(t=-3.99, d f=102, p=.00)$. Thus, it could be concluded that the students' difficulties in learning English speaking with Psychological domain was lower than that of Instructor domain.

\begin{tabular}{|c|c|c|c|c|}
\hline & Mean & $\mathbf{N}$ & Std. Deviation & Std. Error Mean \\
\hline MeanDomain3 & 3.52 & 103 & .59 & .058 \\
\hline MeanDomain4 & 3.88 & 103 & .64 & .063 \\
\hline
\end{tabular}

Table 5: Paired-Samples T-Test of Social and Linguistic Domain

The Paired Samples $t$-Test was run to compare the mean scores of the student's difficulties in learning speaking English with Social and Linguistic domain. The mean score of the students' difficulties in Social domain $(M=3.52, S D=.59)$ was lower than Linguistic domain $(M=3.88, S D=.64)$. The results indicate that there was a significant difference between the students' difficulties in learning English speaking with Social domain and Linguistic domain $(t=-5.65, d f=102, p=.00)$. Thus, it can be concluded that the students' difficulties in learning English speaking with Social domain were lower than those of Linguistic domain.

These above results have shown that the students' difficulties in learning speaking English with Linguistic domain are the highest of the four domains. After Linguistic domain, the students have difficulties learning speaking English with the Instructor domain. However, the students' difficulties with Psychological domain and Social domain are similar.

\subsection{Statistically Significant Differences from Students' Genders}

The Independent Samples t-Test was run to check the difference students' difficulties in learning English speaking between male and female students.

The result of the Independent Samples t- Test on the students' difficulties showed that the mean score of male students $(M=.69, S D=.53)$ was little higher than those of the female students $(M=.60, S D=.34)$. Both groups slightly differ 
significantly ( $t=1.09, d f=101, p=.28)$ in their difficulties of learning speaking English. It could be seen that male students' difficulties in speaking English was little higher than that of the female students. So, there are not any statistically significant differences from the variable of gender of the students. The results also revealed that the male students who encountered difficulties while learning speaking English the same as the female students in the learning speaking process.

\begin{tabular}{|c|c|c|c|c|c|}
\hline & Gender & $\mathbf{N}$ & Mean & Std. Deviation & Std. Error Mean \\
\hline \multirow{2}{*}{ Mean } & Male & 49 & 3.69 & .53 & .075 \\
\cline { 2 - 6 } & Female & 54 & 3.60 & .34 & .046 \\
\hline
\end{tabular}

Table 6: Independent Samples t-Test of students' Difficulties in Learning Speaking

\section{Discussion}

\subsection{The Difficulties That Non-English Majored Freshmen Have Encountered While Learning Speaking English}

The findings supported the hypothesis that non-English majored freshmen at University have faced difficulties in the Instructor domain and Linguistic domain while learning speaking English.

This finding is in line with the finding byGan's (2012), Adayleh (2013), Lin (2014), Izadi (2015) when they confirmed that students faced difficulties in learning speaking skills. These problems consist of lacking vocabulary, focusing much on grammar structures, having limited in-class speaking opportunities, sound recognition, connected speech, and the relation between spelling and sounds, interpreting the intended word meanings, linguistic problems.

Concerning the difficulties of students' speaking in the Instructor domain, this research mentioned teachers' techniques and methods, corrective feedback, how to manage the class, teaching materials when teaching speaking skills. Almost all students understood how their teachers indicated ways of learning speaking English in their classroom. In fact, the participants in this study have faced these problems. This confirms the ideas from Harmer (1991), Brown (2000), Littlewood (2007), Nawshin (2009), Gubaily (2012) and Alhaisoni and Rahman (2013) who asserted the importance of teaching speaking methods, so teachers should change their traditional instruction into student-centred approach. It's essential for the teachers to use some helpful techniques to heighten their students' awareness of these language components in the learning speaking process.

In addition, the findings of this study reveal the students' difficulties in the Linguistic domain through learning speaking English. These issues include students' lack of vocabularies, pronunciation, accent, language grammar, concept of English language. These assertions are consistent with the views about the role of pronunciation while learning how to speak English, as illustrated by Canale\& Swain (1980), Fangzi (1998) and (Fulcher, 2003); about vocabulary of Edward \&Vallette (1997), Laufer (1997) and Goh and Burns (2012).

\subsection{Statistically Significant Differences from Students' Genders}

The data from the questionnaire were conducted to gain significant differences from the variable of gender in learning speaking English. The findings suggest that the male students who encountered difficulties while learning speaking English the same as the female students in the learning speaking process.

It can be seen that male and female students had a general good way to learn speaking English skill and valued its role in their speaking class. They understood what they obtained from the classes which are consistent with their condition, level and standard. Hence, it could be that this teaching method is not complicated and students can implement it in their learning.

Furthermore, the study shows that both male and female students encountered the similar difficulties in speaking English. This result does not accord with Smith and Wilhelm (2002) and Alliance (2007) who indicated that female students' speaking ability was better than male students. Their study confirmed that male students did not overcome the problem in speaking process although male students had a suitable way of dealing with difficulties in speaking.

\section{Conclusions}

Further research should be conducted with a larger sample for making generalization and making the research more valid. It is necessary for future researchers to get insights into their own research into how to teach speaking lessons through modern techniques so that they could enjoy its value. Moreover, further research should be explored the solution for students' difficulties in speaking English; the study should be conducted in different skills such as listening, writing.

It is recommended that teachers need to provide students with a large amount of speaking activities which are related to students' real-life activities, interests, level and prior knowledge. Moreover, an exciting classroom atmosphere with the best learning environment is created in speaking classes so that learners can discuss freely with their partners in the classroom.

It is recommended that learners should become more aware of the value of speaking English and classroom interaction as a way to improve learners' speaking skill.

\section{References}

i. $\quad$ Alhaisoni, M. \& Rahman M. (2013). Teaching English in Saudi Arabia: Prospects and challenges. Retrieved on 16th January 2017 from http://www.journals.savap.org.pk/issue.html.

ii. Alhmadi, N. (2014). English speaking learning barriers in Saudi Arabia: A case study of Taibah University. Arab World English Journal (AWEJ), 5(2), 38-53. 
iii. Alliance, E. (2007). Gender differences in reading achievement: Policy implications and best practices. Charleston, WV: The Education Alliance.

iv. Atallah, A. (2016). Problems of English speaking skill that university students encounter from their perspective. British Journal of Education, Society and Behavioral Science, 18(3), 1-9.

v. Beebe, L. M. (1985). Input: Choosing the right stuff. In. Gass, S. Y. Madden (Eds.), Input in Second Language Acquisition. Rowley, MA: Newbury House.

vi. Biber, D. (2007). Discourse on the move: Using corpus analysis to describe discourse structure. Amsterdam: John Benjamins.

vii. Boyd, D. R., \& Bee, H. (2006). International edition: Lifespan development: 4th Edition. Boston: Pearson Education, Inc.

viii. Brown, H. D. (1980). Principles of language learning and teaching. Englewood Cliffs: Prentice Hall.

ix. Brown, H. D. (2000). Principles of language learning and teaching. San Francisco, CA: Library of Congress Catalog.

x. Brown, H. D. (2001). Language assessment principles and classroom practices. London: Longman.

xi. Brown, H.D. (2001). Teaching by principles: An interactive approach to language pedagogy. White Plains, NY: Longman.

xii. Burns, A., \& Joyce, H. (1997). Focus on speaking. Sydney: National Center for English Language Teaching and Research.

xiii. Canale, M., \& Swain, M. (1980). Theoretical bases of communicative approaches to second language teaching and testing. Applied Linguistics, 1(1), 1-47.

xiv. Creswell, J. W. (2013). Research design: Qualitative, quantitative, and mixed methods approaches. Sage Publications.

xv. Edward, A. D. \&Vallette, R.M. (1997). Classroom technique foreign language and English as a second language. New York: Harcourt Brace Jovanovich.

xvi. Fromkin, V. \& Rodman, R. (1998). An introduction to language. New York, NY: Harcourt Brace College Publishers.

xvii. Fulcher, G. (2003). Testing second language speaking. London: Pearson ESL.

xviii. Goh, C. \& Burns, A. (2012). Teaching speaking: A holistic approach. New York: Cambridge University Press.

xix. Gubaily, M. A.I. (2012). Challenges of teaching and learning spoken English in Yemen. International Journal of Social Science Tomorrow, 1(3), 1-8.

xx. Hadfield, J. (1999). Advanced communication games. England: Addison Wesley Longman Limited.

xxi. Harmer, J. (1991). The practice of English language teaching, Third Edition. Longman: London and New York.

xxii. Harmer, J. (2001). How to teach English: An introduction to the practice of English language teaching. Harlow: Longman.

xxiii. Hedge, T. (2000). Teaching and learning in the language classroom. Oxford: Oxford University Press.

xxiv. Hughes, R. (2002). Teaching and researching speaking. New York: Pearson Education.

xxv. Jeffrey, C., \& Stacy, M. (2003). English grammar. New York: Wiley Publishing.

xxvi. Juhana, J. (2012). Psychological factors that hinder students from speaking in English class (A case study in a Senior High School in South Tangerang, Banten, Indonesia). Journal of Education and Practice, 3 (12), 100-110.

xxvii. Kayi, H. (2006). Teaching speaking: Activities to promote speaking in a second language. The internet TESL journal. Vol. XII, No. 11.

xxviii. Krashen, S. D. (1982). Principles and practice in second language acquisition. Oxford: Pergamon.

xxix. Kumaravadivelu, B. (2006). Understanding language teaching from methods to postmethod: ESL \& applied linguistics professional series. Lawrence Erlbaum Associates, Inc., Publishers Mahwah, New Jersey.

xxx. Khamkhien, A. (2010). Teaching English speaking and English speaking tests in the Thai context: A reflection from Thai perspectives. English Language Journal. 3(1):184-200.

xxxi. Laufer, B. (1997). What's in a word that makes it hard or easy? Intra-lexical factors affecting the difficulty of vocabulary acquisition. In McCarthy, M. \& Schmitt, M (1997), Vocabulary description, acquisition and pedagogy. Cambridge: Cambridge University Press. p. 140-155.

xxxii. Michael, S. (2005). Grammar. Oxford: Oxford University Press.

xxxiii. Nawshin, F. 2009. Problems in teaching in traditional ESL classrooms.1-22. Dhaka: Brac University Press (Bangladesh).

xxxiv. Nunan, D. (2003). Practical English language teaching. New York : McGraw Hill.

xxxv. Nunan, D. (2015). Teaching English to speakers of other languages: An introduction. New York, NY: Routledge.

xxxvi. Scoot,T. (2005). How to teach speaking. Longman, England.

xxxvii. Smith, M. W., \& Wilhelm, J. D. (2002). Reading doesn't fix nochevys: Literacy in the lives of young men. Portsmouth: Heinemann.

xxxviii. Tymson, C. (1998). Gender games: Doing business with the opposite sex. Australia: Tymson Communication.

xxxix. Ur, P. (1996). A course in language teaching. Cambridge: Cambridge University Press.

xl. Wong-Fillmore, L. (1989). Language learning in social context: The view from research in second language learning. In R. Dietrich \& C. F. Graumann (Eds.), Language processing in social context (Volume 54, pp. 277302). Amsterdam: Elsevier. 